\title{
AGGRESSIVENESS BETWEEN GENETIC GROUPS I AND II OF ISOLATES OF Cercospora zeae-maydis
}

\author{
Sandra Marisa Mathioni ${ }^{1}$; Roberto Venceslau de Carvalho ${ }^{2}$; Kátia Regiane Brunelli ${ }^{3}$; André \\ Beló $^{1}$; Luis Eduardo Aranha Camargo ${ }^{3 *}$ \\ ${ }^{1}$ USP/ESALQ - Programa de Pós-Graduação em Genética e Melhoramento de Plantas. \\ ${ }_{3}^{2}$ Dow AgroSciences Industrial Ltda, Rod. Anhanguera Km 344, C.P. 47 - 14680-000 - Jardinópolis, SP - Brasil. \\ ${ }^{3}$ USP/ESALQ - Depto. de Entomologia, Fitopatologia e Zoologia Agrícola, C.P. 09 - 13418-900- Piracicaba, \\ $S P$ - Brasil. \\ *Corresponding author <leacamar@esalq.usp.br>
}

\begin{abstract}
For many years, the gray leaf spot disease (GLS) caused by the fungus Cercospora zeaemaydis Tehon \& Daniels, was not considered an important pathogen of maize (Zea mays, L.) in Brazil. However, the recent adoption of agronomical practices such as no-tillage and cultivation under central pivot irrigation systems increased the incidence and severity to the extent that GLS is now one of the most important diseases of maize. Isolates of C. zeae-maydis can be distinguished by two genetic groups (I and II) based on AFLP markers and on polymorphisms of the ITS and 5.8S rDNA regions. Until now, however, the biological implications of this distinction remain unclear. This study investigated whether isolates from the two genetic groups differ in aggressiveness towards maize. For this, symptoms of a susceptible hybrid were evaluated under greenhouse conditions with 9 and 11 isolates of $C$. zeae-maydis from groups I and II, respectively. Plants in the V3 growth stage were inoculated by placing sorghum seeds colonized with the pathogen in the leaf whorl and symptoms were evaluated with a visual rating scale 30 days later. On average, isolates of genetic group II were more aggressive than those of group I, with mean disease scores of 3.1 and 2.3, respectively. Differences were also observed between experiments, which suggested that group I and II might also differ in their fitness under different environments. This is the first report on differences in aggressiveness between the two genetic groups of $C$. zeae-maydis.
\end{abstract}

Key words: disease resistance, gray leaf spot, genetic variability, pathogenicity

\section{AGRESSIVIDADE ENTRE ISOLADOS DOS GRUPOS GENÉTICOS I E II DE Cercospora zeae-maydis}

\begin{abstract}
RESUMO: Durante muitos anos, a cercosporiose, causada pelo fungo Cercospora zeae-maydis Tehon \& Daniels, não foi considerada importante para a cultura do milho (Zea mays, L.) no Brasil. Entretanto, a recente utilização de práticas culturais como o plantio direto e o cultivo sob pivôs centrais favoreceram o aumento de sua severidade e incidência, de forma que a doença é hoje considerada uma das mais importantes da cultura. Isolados de C. zeae-maydis podem ser distinguidos em dois grupos genéticos (I e II) baseados em marcadores AFLP e polimorfismos das regiões ITS e rDNA 5.8S. Até o momento, no entanto, a implicação biológica de tal distinção não é conhecida. Este trabalho objetivou determinar se isolados dos dois grupos genéticos diferem em agressividade em milho. Para tal, sintomas de um híbrido suscetível foram avaliados sob condições de casa de vegetação após inoculação com 9 e 11 isolados de $C$. zeaemaydis dos grupos I e II, respectivamente. Plantas no estádio V3 foram inoculadas através do depósito de sementes de sorgo colonizadas pelo patógeno no cartucho. Os sintomas foram avaliados 30 após com uma escala visual. Em média, isolados do grupo genético II foram mais agressivos que os do grupo I, com índices médios de doença de 3.1 e 2.3, respectivamente. Também observamos diferenças entre experimentos que sugerem diferenças em adaptabilidade dos grupos I e II a ambientes diferentes. Este é o primeiro relato de diferenças em agressividade entre isolados dos dois grupos genéticos de C. zeae-maydis.

Palavras-chave: resistência a doenças, cercosporiose, variabilidade genética, patogenicidade
\end{abstract}

\section{INTRODUCTION}

Gray leaf spot, caused by the fungus Cercospora zeae-maydis Tehon \& Daniels, is one of the main diseases of maize (Zea mays, L.) in several countries, causing severe losses of up to $65 \%$ (Donahue et al., 1991; Ward \& Nowell, 1998; Ward et al., 1999). The main control strategy is to use resistant hybrids (Munkvold et al., 2001). However, there are reports from breeders that, in some regions, resistant hybrids are susceptible to the pathogen (Fantin et al., 2001). This observation suggests that there is an interaction 
between maize genotypes and environments that could result from the low genetic stability of the hybrids and from the existence of physiological races of the pathogen in different areas, or both. Several studies were performed with the objective to genetically characterize isolates of C. zeae-maydis (Wang et al., 1998; Dunkle \& Levy, 2000; Brunelli, 2004). Using RFLP markers in the ITS region of the $5.8 \mathrm{~S}$ of the rDNA and AFLP markers, Wang et al. (1998) were able to distinguish more than 100 isolates collected from different areas in the USA separating them into two genetic groups, named groups I and II. Along the same line, Brunelli (2004) identified the same groups from 69 isolates collected in Brazil. In addition, Bair \& Ayers (1986), Dunkle \& Carson (1998), Carson et al. (2002), and Brunelli (2004) demonstrated the existence of differences in aggressiveness among isolates of $C$. zeaemaydis but did not establish any relationship between these differences and their genetic groups. Thus, until now, levels of aggressiveness between groups I and II have not been studied. The objective of this study was to compare the aggressiveness of isolates belonging to the genetic groups I and II collected in regions of maize cultivation in Brazil.

\section{MATERIAL AND METHODS}

\section{Inoculum preparation}

Twenty Brazilian isolates of $C$. zeae-maydis collected in distinct regions and previously characterized by Brunelli (2004) as belonging to either group I (9 isolates) or II (11 isolates) (Table 1) were used in this study. Isolates stored in sterile deionized water at $4^{\circ} \mathrm{C}$ were transferred to PDA medium $\left(200 \mathrm{~g} \mathrm{~L}^{-1}\right.$ of potato, $20 \mathrm{~g} \mathrm{~L}^{-1}$ of dextrose, and $14 \mathrm{~g} \mathrm{~L}^{-1}$ of agar) and incubated for seven days at $27 \pm 2^{\circ} \mathrm{C}$ with $12 \mathrm{hrs}$ of light and $12 \mathrm{hrs}$ of darkness. After that, they were transferred to tomato juice medium (STT - $200 \mathrm{~mL}$ of SuperBom $^{\circledast}$ tomato juice, $3 \mathrm{~g}$ of $\mathrm{CaCO}_{3}, 14 \mathrm{~g}$ of agar, and $800 \mathrm{~mL}$ of sterile water) and incubated at $25 \pm 2{ }^{\circ} \mathrm{C}$ under $12 \mathrm{hrs}$ of light and $12 \mathrm{hrs}$ of darkness for 15 days (Brunelli et al., 2006). Inoculum was prepared transferring five medium plugs colonized with the pathogen to sterile $125 \mathrm{~mL}$ Erlenmeyer flasks containing 20 $\mathrm{g}$ of sterile sorghum seeds and $16 \mathrm{~mL}$ of water. Cultures were kept at $25^{\circ} \mathrm{C}$ under $12 \mathrm{hrs}$ of light and 12 hrs of darkness for 15 days. Sorghum seeds were sterilized in autoclave.

\section{Evaluation of aggressiveness}

The aggressiveness of $C$. zeae-maydis isolates was determined under greenhouse conditions using a four-complete randomized block experimental design in which each plot was represented by a pot $(0.3 \mathrm{~m} \times$
Table 1 - Origin of isolates of genetic groups I and II of Cercospora zeae-maydis.

\begin{tabular}{ll}
\hline Isolate & \multicolumn{1}{c}{ Location } \\
\hline Genetic group I & Cachoeira Dourada, MG \\
CD 3.1 & Guaíra, SP \\
GUA 5 & Indianópolis, MG \\
\hline I 7.1 & Jardinópolis, SP \\
\hline JA 3.1 & Luis Eduardo Magalhães, BA \\
\hline LEM & Piracicaba, SP \\
PIRA 4 & Piracicaba, SP \\
\hline PIRA 7.1 & Unaí, MG \\
U 1.2 & Unaí, MG \\
\hline U 2.3 & \\
\hline Genetic group II & Castro, PR \\
\hline CASTRO & Cristalina, GO \\
CRIS A & Indianópolis, MG \\
\hline I 10 & Indianópolis, MG \\
\hline I 9.2 & Iraí de Minas, MG \\
\hline IRAI 4.1 & Miguelópolis, SP \\
\hline MIG 1.1 & Miguelópolis, SP \\
MIG F & Perolândia, GO \\
PER & Uberlândia, MG \\
\hline UBER 2 & Uberlândia, MG \\
UBER 3 & Uberlândia, MG \\
\hline UBER 9 & \\
\hline & \\
\hline
\end{tabular}

$0.2 \mathrm{~m}$ each) containing three plants of the susceptible hybrid DAS-8392, repeating the first experiment from September to October, 2004 and the second from March to April, 2005.

Maize plants from the hybrid DAS-8392 were inoculated in the vegetative stage V3 (Ritchie et al., 1993) when plants had four expanded leaves (about 25 days after emergence) placing 10 sorghum seeds colonized with the pathogen in the whorl of leaves. After inoculation and during the subsequent four days, pots were kept in a dew chamber for $16 \mathrm{hrs}$ per day. The experiment was conducted under high humidity $( \pm 95 \%)$ conditions achieved by daily watering of the greenhouse.

Symptoms were evaluated on leaves 5 and 6 of each plant 30 days post inoculation, when lesions were easily visible. For this, a diagrammatic scale developed by Brunelli (2004) consisting of four scores based on the number of lesions per leaf was used. In this scale, score 1 corresponds to leaves without symptoms, 2 corresponds to leaves with less than 10 chlorotic spots, 3 corresponds to leaves with $>10$ of both chlorotic and elongated necrotic lesions delimited by major leaf veins including some with sporulating spots, and score 4 to leaves with $>20$ of both such lesion types. 


\section{Statistical analysis}

The mean score $Y$ from each plot was transformed according to $\sqrt{(Y+1)}$ and used in the analysis of variance and multiple contrast tests (Tukey) using the statistical package SAS (versão 8.1 - SAS Institute, 1991).

\section{RESULTS AND DISCUSSION}

The average temperatures during the first and second experiments were $27^{\circ} \mathrm{C}$ and $29^{\circ} \mathrm{C}$, respectively and the mean relative humidity was $95 \%$. According to Paul \& Munkvold (2005), these conditions are considered ideal for the development of the gray leaf spot. The maintenance of high humidity in the greenhouse and the use of the dew chamber in the first four days after inoculation helped to maintain these high humidity conditions needed for the survival of spores and infection of plants (Beckman \& Payne, 1983; Thorson \& Martinson, 1993; Asea et al., 2005). The first characteristic symptoms of GLS were observed after a period that corresponded to the reported latent period of this disease under field conditions (14-28 days), according to Latterell \& Rossi (1983), thus indicating that the infection process in the greenhouse environment was similar to that expected in the field.

The coefficient of variation $(5.57 \%)$ observed for both experiments is acceptable according to Pimentel-Gomes \& Garcia (2002), suggesting good experimental precision. These authors reported that experiments conducted under well controlled conditions, like experiments in laboratory or greenhouse, usually present low coefficients of variation, sometimes lower than 5\%.

Significant differences were observed in aggressiveness among isolates both between and within genetic groups (Table 2; Figure 1). The mean disease scores of isolates from groups I and II were 2.30 and 3.14, respectively, indicating that isolates from group II were, on average, more aggressive than those from group I. A significant variation within groups was also detected. For instance, isolates I 10 and I 9.2, from group II, and I 7.1, from group I, were collected in the same place (Indianópolis, MG) but differed in aggressiveness (Figure 1), indicating variation for this important trait within populations of C. zeae-maydis. This suggests that aggressiveness is an intrinsic characteristic of the individual and not of the population within of a given area.

Differences in aggressiveness among isolates of C. zeae-maydis were reported earlier but were not related to their genetic background. Bair \& Ayers (1986), for instance, inoculated 15 isolates in four susceptible hybrids, both in greenhouse and in the field and found significant variations in lesion length and in disease severity among isolates. However, at that
Table 2 - Analysis of variance of the mean aggressiveness of isolates of genetic groups I and II of Cercospora zeae-maydis inoculated in the maize hybrid DAS-8392.

\begin{tabular}{lrcc}
\hline Sources of Variation & $\mathrm{dF}$ & $\mathrm{MS}^{\mathrm{a}}$ & $\mathrm{P}>\mathrm{F}^{\mathrm{b}}$ \\
\hline Isolate (I) & 19 & 0.1444 & $<0.0001^{* * *}$ \\
$\quad$ GI & 8 & 0.1155 & $<0.0001^{* * *}$ \\
$\quad$ GII & 10 & 0.0382 & $<0.0001^{* * *}$ \\
$\quad$ GI vs. GII & 1 & 1.4374 & $<0.0001^{* * *}$ \\
Experiment (E) & 1 & 0.0200 & $0.1937^{\mathrm{NS}}$ \\
$\quad \mathrm{I} \times \mathrm{E}$ & 19 & 0.0558 & $<0.0001^{* * *}$ \\
Error & 114 & 0.0117 & \\
\hline Total & 159 & & \\
\hline Mean $^{\mathrm{a}}$ & 1.94 & & \\
\hline $\mathrm{CV}(\%)^{\mathrm{a}}$ & 5.57 & & \\
\hline
\end{tabular}

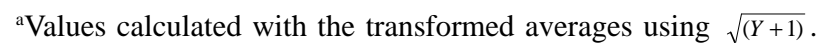
${ }^{b}$ Values significant with probability $<" 0.05,{ }^{* *} 0.01,{ }^{* * * *} 0.001$ $\left({ }^{\mathrm{NS}}=\right.$ non-significant $)$

GI and GII refer to the genetic groups of C. zeae maydis

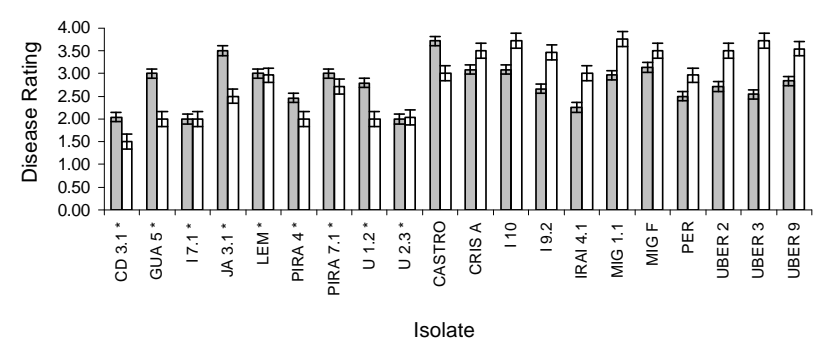

Figure 1 - Mean disease severity \pm standard-error of isolates of $C$. zeae-maydis inoculated in the maize hybrid DAS- 8392 under greenhouse conditions, in the first (gray bars) and second (white bars) experiments. $(*)$ indicates that the isolate belongs to genetic group I whereas unmarked isolates belong to genetic group II.

time, the existence of genetic groups within C. zeaemaydis was not yet established. Dunkle \& Carson (1998) evaluated seven isolates of C. zeae-maydis under field conditions, four being from group I and three from group II and observed a broad variation in aggressiveness within genetic groups, but not between groups. However, the authors indicated the need for a more extensive study with more isolates in order to conclude that there is no variation in aggressiveness between groups. Carson et al. (2002) also reported on the variation in aggressiveness among isolates, but used only one isolate from group II. Finally, Okori et al. (2004) studied 27 African isolates of $C$. zeae-maydis all belonging to group II and also reported significant differences in aggressiveness between isolates. Thus, our results are the first relating such differences to the established genetic groups of this pathogen. 
The biological basis of this phenomenon remains to be determined but it is here speculated that this may be due, at least in part, to the production of the phytotoxin cercosporin. Dunkle \& Carson (1998) reported that group II isolates grow slower and do not produce or produce a lower amount of cercosporin in culture. Under light, cercosporin generates toxic reactive oxygen intermediates that lead to host cell death (Daub \& Ehrenshaft, 2000). Besides, these intermediates are recognized elicitors of defense mechanisms of the plant (Dangl et al., 1996). Therefore, if the production of cercosporin in the host is the same as in the culture, then Group I isolates would produce greater amounts of cercosporin upon infection resulting in the early activation of host responses and therefore a lower degree of aggressiveness as compared to Group II isolates.

Another finding was that significant interactions were found among isolates and experiments (Table 2, Figure 1). Of special relevance was that the mean aggressiveness of Group I isolates was higher in the first experiment than in the second (2.64 and 1.86 , respectively), whereas the opposite ( 2.85 and 3.42 , respectively) occurred for isolates of Group II (Figure 1). This could result from differences in environmental conditions since the experiments were conducted in different seasons. In the second experiment, for instance, the mean maximum and minimum temperatures $\left(30.0\right.$ and $18.2^{\circ} \mathrm{C}$, respectively) were higher than in the first $\left(29.0\right.$ and $15.7{ }^{\circ} \mathrm{C}$, respectively). It is known that environmental factors have a tremendous effect on GLS development, especially relative humidity and temperature (Ward et al., 1999, Beckman \& Payne, 1982). However, our observations further suggest that, in addition to differences in aggressiveness, Group I and II isolates might also differ in their fitness under different environments. This fact might be of special relevance in Brazil, where maize is cultivated under a wide variety of conditions, ranging from cool and dry summers in Southeast as compared to the Central Region. There might also be marked variations between the two main planting seasons within a region. In Central and Southeast Brazil, for example, GLS epidemics are more severe for the late cropping season, which normally begins in January and extends in April, when temperatures, relative humidity and solar radiation levels towards the end of the cycle are lower than in the normal season, which begins in November/December. Thus, it would be important to assess the frequencies of both groups in different regions and during different cropping seasons in order to establish a relationship, if any, between shifts in frequencies and greater or lower severities of GLS.
Carson et al. (2002) noted that less aggressive isolates were less efficient in discriminating resistance levels of maize hybrids, indicating the importance of knowing their level of aggressiveness in order to maximize the selection gain when relying on artificial inoculation to evaluate the resistance of maize plants to gray leaf spot. Thus, our study further corroborates with this conclusion.

\section{ACKNOWLEDGEMENT}

To CNPq for providing a scholarship to the first author through grant number 133529/2004-5.

\section{REFERENCES}

ASEA, G.; LIPPS, P.E.; PRATT, R.C.; GORDON, S.G.; ADIPALA, E. Development of greenhouse inoculation procedures for evaluation of partial resistance to Cercospora zeae-maydis in maize inbreds. Journal of Phytopathology, v.153, p.647-653, 2005.

BAIR, W.; AYERS, J.E. Variability in isolates of Cercospora zeaemaydis. Phytopathology, v.76, p.129-132, 1986.

BECKMAN, P.M.; PAYNE, G.A. External growth, penetration, and development of Cercospora zeae-maydis in corn leaves. Phytopathology, v.72, p.810-815, 1982.

BECKMAN, P.M.; PAYNE, G.A. Cultural techniques and conditions influencing growth and sporulation of Cercospora zeae-maydis and lesion development in corn. Phytopathology, v.73, p.286-289, 1983.

BRUNELLI, K.R. Cercospora zeae-maydis: Esporulação, Diversidade Morfo-Genética e Reação de Linhagens de Milho. Piracicaba: USP/ ESALQ, 2004. 105p. (Tese Doutorado).

BRUNELLI, K.R.; FAZZA, A.C.; ATHAYDE SOBRINHO, C.; CAMARGO, L.E.A. Efeito do meio de cultura e do regime de luz na esporulação de Cercospora zeae-maydis. Summa Phytopathologica, v.32, p.92-94, 2006.

CARSON, M.L.; GOODMAN, M.M.; WILLIAMSON, S.M. Variation in aggressiveness among isolates of Cercospora from maize as a potential cause of genotype-environment interaction in gray leaf spot trials. Plant Disease, v.86, p.1089-1093, 2002.

DANGL, J.L.; DIETRICH, R.A.; RICHBERG, M.H. Death don't have no mercy: cell death programs in plant-microbe interactions. The Plant Cell, v.8, p.1793-1807, 1996.

DAUB, M.E.; EHRENSHAFT, M. The photoactivated Cercospora toxin cercosporin: contributions to plant disease and fundamental biology. Annual Reviews of Phytopathology, v.38, p.461-490, 2000.

DONAHUE, P.J.; STROMBERG, E.L.; MYERS, S.L. Inheritance of gray leaf spot in a diallel cross of 14 maize inbreds. Crop Science, v.31, p.926-931, 1991.

DUNKLE, L.D.; CARSON, M.L. Genetic variation in Cercospora and the potential impact on selecting for resistance to gray leaf spot of corn. In: ANNUAL CORN AND SORGHUM RESEARCH CONFERENCE, 53., Chicago, 1998. Proceedings. Washington: American Seed Trade Association, 1998. p.334-347.

DUNKLE, L.D.; LEVY, M. Genetic relatedness of African and United States populations of Cercospora zeae-maydis. Phytopathology, v.90, p.486-490, 2000.

FANTIN, G.M.; BRUNELLI, K.R.; RESENDE, I.C.; DUARTE, A. A mancha de cercospora do milho. Campinas: IAC, 2001. (Boletim Técnico, 192).

LATTERELL, F.M.; ROSSI, A. Gray leaf spot of corn: a disease on the move. Plant Disease, v.67, p.842-847, 1983.

MUNKVOLD, G.P.; MARTINSON, C.A.; SHRIVER, J.M.; DIXON, P.M. Probabilities for profitable fungicide use against gray leaf spot in hybrid maize. Phytopathology, v.91, p.477-484, 2001. 
OKORI, P.; RUBAIHAYO, P.R.; ADIPALA, E.; DIXELIUS, C. Interactive effects of host, pathogen and mineral nutrition on gray leaf spot epidemics in Uganda. European Journal of Plant Pathology, v.110, p.119-128, 2004.

PAUL, P.A.; MUNKVOLD, G.P. Influence of temperature and relative humidity on sporulation of Cercospora zeae-maydis and expansion of gray leaf sport lesions on maize leaves. Plant Disease, v.89, p.624630, 2005.

PIMENTEL-GOMES, F.; GARCIA, C.H. Estatística aplicada a experimentos agronômicos e florestais. Piracicaba: FEALQ, 2002. $309 \mathrm{p}$.

RITCHIE, S.W.; HANWAY, J.J.; BENSON, G.O. How a corn plant develops. Iowa: Iowa State University of Science and Technology, 1993. 20p. (Special Report, 48).

SAS INSTITUTE. SAS/STAT procedure guide for personal computers. 5.ed. Cary: SAS Institute, 1991. 1104p.
THORSON, P.R.; MARTINSON, C.A. Development and survival of Cercospora zeae-maydis germlings in different relative-humidity environments. Phytopathology, v.83, p.153-157, 1993.

WANG, J.; LEVY, M.; DUNKLE, L.D. Sibling species of Cercospora associated with gray leaf spot of maize. Phytopathology, v.88, p.1269-1275, 1998.

WARD, J.M.J.; NOWELL, D.C. Integrated management for the control in maize gray leaf spot. Integrated Pest Management Reviews, v.3, p.1-12, 1998.

WARD, J.M.J.; STROMBERG, E.L.; NOWELL, D.C.; NUTTER JR, F.W. Gray leaf spot - A disease of global importance in maize production. Plant Disease, v.83, p.884-895, 1999.

Received April 07, 2006

Accepted October 26, 2006 